\title{
Dowódca Referatu II Armii Krajowej z Gestapo - Eugeniusz Adamczyk „Wiktor”
}

\begin{abstract}
Abstrakt: Celem artykułu jest przybliżenie postaci Eugeniusza Adamczyka, niedocenionego bohatera podziemia niepodległościowego z czasów II wojny światowej. Pełniąc w Armii Krajowej ważną funkcję dowódcy wywiadu i kontrwywiadu Obwodu Jędrzejów, a następnie szefa wywiadu Okręgu Radomsko-Kieleckiego, przeniknął jednocześnie do struktur Gestapo. Pracując dla kryminalnej policji Kripo, wykorzystywał swoją pozycję i wiedzę m.in. do ratowania Polaków przed aresztowaniami przez Niemców, ułatwiał odbijanie więźniów, pomógł zorganizować udany zamach na życie Helmuta Kappa, zastępcy dowódcy Gestapo w Jędrzejowie.
\end{abstract}

Słowa kluczowe: Eugeniusz Adamczyk, Armia Krajowa, kontrwywiad, II wojna światowa

Dotychczas — osiemdziesiąt lat od wybuchu II wojny światowej — ukazało się wiele prac poświęconych działaczom polskiego podziemia niepodległościowego, zwłaszcza członkom Armii Krajowej. Celem artykułu jest przybliżenie sylwetki jednego z nich - Eugeniusza Adamczyka.

Na pierwszy ślad jego działalności natrafiłam w Archiwum Instytutu Pamięci Narodowej, przeglądając sporządzone w 1963 roku ankiety dotyczące byłych członków niepodległościowych organizacji1 ${ }^{1}$. E. Adamczyk urodził się 10 października 1911 roku w Irządzach. Był synem Franciszka i Julii (z d. Popioł). W czasie sporządzania ankiety (1963) mieszkał w Gliwicach i był administratorem budynków Wydziału Górniczego Politechniki Śląskiej².

W 1925 roku ukończył siedmioklasową szkołę powszechną w Irządzach, cztery lata potem jego rodzice przenieśli się do Podsadka koło Jędrzejowa, gdzie nabyli

\footnotetext{
${ }^{1}$ Archiwum Instytutu Pamięci Narodowej (dalej: AIPN), sygn. Ka 032/29, Ankiety osobowe badanych byłych członków AK i WiN, k. 31-37.

2 Ibidem, k. 31. Nieprawdziwa informacja o pochodzeniu E. Adamczyka z Rybnika w: M. SoŁTYSIA K: Chłopcy „Barabasza”. Warszawa 1971, s. 17.
} 
gospodarstwo rolne. Bohater artykułu pomagał rodzicom w pracy, zaangażowany był również w działalność Związku Strzeleckiego w Mstyczowie — kuźni kadr dla wojska i patriotycznej szkoły wychowania ${ }^{3}$.

Po ukończeniu szkoły średniej w roku 1931 E. Adamczyka powołano do zasadniczej służby wojskowej w 3. Pułku Piechoty Legionów w Jarosławiu. Po jej odbyciu został zwolniony jako nadterminowy do roku 1936, na tym etapie karierę wojskową kończąc w stopniu plutonowego ${ }^{4}$. Wstąpił do policji, ukończył szkołę policyjną w Mostach Wielkich (woj. lwowskie). W 1936 roku rozpoczął pracę w policji mundurowej w Wydziale Przestępstw Kryminalnych. Służbę zaczął pełnić na posterunku w Mszanie koło Lwowa, jednak po zatargu ze zwierzchnikami został przeniesiony do Potutorów koło Brzeżan. Pracował także w Urzędzie Śledczym we Lwowie jako fotograf i specjalista od daktyloskopii ${ }^{5}$. Po wybuchu wojny przeszedł do służby wojskowej i walczył w obronie Lwowa ${ }^{6}$. Został ujęty przez Armię Czerwoną i osadzony w więzieniu w Złoczowie. Opuścił więzienie podstępem - ponieważ nie miał przy sobie dokumentów, podał się za cywila i dzięki temu udało mu się wyjść 725 listopada 1939 roku - mieszkając nadal we Lwowie - ożenił się z Adelą Rudawiec. 26 grudnia został aresztowany przez NKWD, lecz po kilku dniach podstępem ponownie uciekł z więzienia i zamieszkał w Samborze. W maju 1940 roku przekroczył granicę i udał się do rodzinnego domu we wsi Podsadek ${ }^{8}$.

Podczas wojny - jako „Wiktor” - był członkiem konspiracyjnych organizacji ZWZ i AK, działających na terenie Jędrzejowa' ${ }^{9}$. Był inicjatorem powstałej 25 maja 1940 roku w Podsadku tajnej organizacji wojskowej o nazwie „Mściciel”. Najbliższym współpracownikiem „Wiktora” w tym dziele był Jan Porwoł, były powstaniec śląski z Kosztów koło Mysłowic, który ukrywał się przed Niemcami w Mstyczowie. W końcu sierpnia 1940 roku organizacja „Mściciel” liczyła prawie 40 członków, przeprowadziła kilka drobnych akcji sabotażowo-dywersyjnych, dysponując przy tym tylko 6 karabinami i 3 pistoletami wraz z amunicją, i wydała 12 numerów gazetki „Mściciel” (były to przepisywane na maszynie komunikaty z nasłuchu radiowego). Z powodu zagrożenia organizacji ze strony Gestapo w Miechowie jesienią

${ }^{3}$ Z. BiaŁkiewicZ: Mowa pożegnalna wygłoszona przez ppor. AK Zbigniewa Białkiewicza nad trumna zmarlego ppor. AK Eugeniusza Adamczyka „Wiktora”. W: E. ADAмсzy к ps. „Wiktor”: Mój udział w kontrwywiadzie Armii Krajowej. Warszawa 2007, s. 277.

${ }^{4}$ AIPN, sygn. Ka 02/132, T. 1, Kwestionariusz ewidencyjny kryptonim „Nieugięty” dot. Adamczyk Eugeniusz, k. 47.

${ }^{5}$ Ibidem; AIPN, sygn. Ka 032/29, Ankiety osobowe..., k. 31; E. AdAмсZYк ps. „Wiktor”: Mój udział w kontrwywiadzie..., s. 7; Z. BIAєKIEWICZ: Mowa pożegnalna..., s. 277.

${ }^{6}$ AIPN, sygn. Ka 02/132, T. 1, Kwestionariusz ewidencyjny..., k. 47.

7 Ibidem; E. AdAMCZy к ps. „Wiktor”: Mój udział w kontrwywiadzie..., s. 22-25.

8 AIPN, sygn. Ka 02/132, T. 1, Kwestionariusz ewidencyjny..., k. 47; E. ADAмсzy к ps. „Wiktor”: Mój udział w kontrwywiadzie..., s. 42-57.

9 AIPN, sygn. Ka 032/29, Ankiety osobowe..., k. 32. 
1940 roku zawieszono jej działalność, a 17 grudnia kilkunastu członków „Mściciela” zaprzysiężono w Swaryszowie pod Sędziszowem do ZWZ10.

We wrześniu 1940 roku E. Adamczyk uciekł do Kielc, gdzie spotkał kolegów z wojska, którzy wprowadzili go w szeregi ZWZ. W organizacji tej rozpowszechniał gazetki oraz zdobywał zaopatrzenie. Opiekował się także tajnym szkolnictwem i prowadził kartotekę zbrodni niemieckich ${ }^{11}$. Według relacji Zygmunta Żywockiego w powiecie jędrzejowskim, gdzie konstytuowały się konspiracyjne struktury organizacyjne, z których wyrosła Armia Krajowa, E. Adamczyk brał czynny udział w działalności wywiadu i kontrwywiadu organizacji ${ }^{12}$. Był kierownikiem kontrwywiadu przy II Referacie AK na Obwód Jędrzejów, a następnie kierownikiem całego II Referatu tegoż obwodu. Za wiedzą przełożonych w lutym 1941 roku wstąpił do niemieckiej policji kryminalnej w Jędrzejowie, gdzie pracował do sierpnia 1944 roku, prowadząc dział fotograficzny i daktyloskopijny ${ }^{13}$. Kiedy Niemcy zaproponowali mu współpracę, zgodził się. Przekazywał hitlerowcom informacje prefabrykowane przez zwierzchników, prowadził skrupulatne zapiski ze swej działalności ${ }^{14}$. Zeznania E. Adamczyka w sprawie jego roli w Gestapo potwierdza relacja Andrzeja Ropelewskiego „Karasia”, znanego członka AK. Praca w Gestapo umożliwiła „Wiktorowi” uratowanie życia Stanisławowi Boryniowi „Tygrysowi”, który przed wojną był plutonowym broni pancernej w Żurawicy koło Przemyśla. Od końca 1939 roku S. Boryń działał w konspiracji na terenie Sędziszowa. Wiosną 1941 roku został aresztowany. Więziono go w siedzibie Gestapo w Jędrzejowie, skąd już po dwóch tygodniach uciekł dzięki pomocy E. Adamczyka ${ }^{15} .22$ maja 1943 roku E. Adamczyk będąc w Irządzach, gdzie miał na polecenie Niemców zidentyfikować zwłoki mężczyzny zastrzelonego poprzedniego dnia przez granatową policję, przekazał Tadeuszowi Dudkiewiczowi, członkowi tamtejszego AK, informacje o planowanym aresztowaniu Stefana Czubaka, kierownika mleczarni w Chlewicach. Dzięki tym wiadomościom zdołano w ostatniej chwili uratować S. Czubaka ${ }^{16}$.

${ }^{10}$ A. Ropelewski „Karaś”: Oddział partyzancki „Spaleni”. Toruń 2000, s. 200.

${ }^{11}$ AIPN, sygn. Ka 02/132, T. 1, Kwestionariusz ewidencyjny..., k. 47.

12 A. Ropelewski: W Jędrzejowskim Obwodzie AK. Warszawa 1986, s. 67.

13 AIPN, sygn. Ka 032/29, Ankiety osobowe..., k. 32.

${ }_{14}$ AIPN, sygn. Ka 02/132, T. 1, Kwestionariusz ewidencyjny..., k. 47.

15 A. Ropelewski „Karaś”: Oddział partyzancki..., s. 20. Zob. także: A. SoKó£: Ruch oporu w regionie jędrzejowskim w latach okupacji niemieckiej. „Studia Historyczne” 1987, t. 30, 2 (117), s. 267.

${ }^{16}$ E. АрАмсzук ps. „Wiktor”: Mój udział w kontrwywiadzie..., s. 143-144. Co ważne, zarówno uratowanie „Tygrysa”, jak i Stefana Czubaka potwierdzają materiały przechowywane w zbiorach IPN - są to odpowiednio zeznania Stanisława Borynia „Tygrysa” i Tadeusza Dudkiewicza, zob. AIPN, sygn. Ki 126/60, Akta sprawy karnej przeciwko: Adamczyk Eugeniusz oskarżonemu z art. 1 pkt 2 i art. $4 \$ 1$ Dekretu PKWN z dn. 31-08-1944 r. o wymiarze kary dla faszystowsko-hitlerowskich zbrodniarzy winnych zabójstw i znęcania się nad ludnością cywilną i jeńcami oraz dla zdrajców Narodu Polskiego, tj. o współpracę z niemiecką Sicherheitsdienst, k. 286, 291. 
Jedną z największych akcji podziemnego wojska w Obwodzie Jędrzejów była likwidacja Helmuta Kappa, zastępcy dowódcy Gestapo w Jędrzejowie. W ciągu swojej dwuipółletniej „kadencji” miał on zamordować osobiście 87 Polaków i ok. 350 Żydów, o czym publicznie opowiadał ${ }^{17}$. Zamachu na mordercę dokonała miejska grupa dywersyjna AK w składzie: por. Hieronim Piasecki „Zola”, ppor. Zdzisław Kajderowicz „Ryszard” i Witold Staszkiewicz „Wituś”. Akcję przeprowadzono 31 maja 1943 roku w Jędrzejowie. Rozkaz zlikwidowania H. Kappa wydał mjr Stefan Gądzio „Kos”, komendant Obwodu Jędrzejów AK, działając w porozumieniu z E. Adamczykiem. Likwidacja H. Kappa pociągnęła jednak za sobą represje, w wyniku których w czerwcu 1943 roku rozstrzelano w Jędrzejowie 11 Polaków, a 22 wywieziono do obozów ${ }^{18}$.

1 lutego 1944 roku S. Gądzio „Kos” wydał rozkaz odbicia z jędrzejowskiej siedziby Gestapo 5 aresztowanych poprzedniego dnia ludzi związanych z AK: Adama Grabowskiego „Mocnego”, jego syna Zbigniewa „Czarnego”, Stanisława Białkiewicza „Zarębę" z synem Zbigniewem „Świerkiem” oraz Stanisława Skowronka „Pniaka” (wcześniej Gestapo aresztowało żołnierza AK — niejakiego Henryka Blicharskiego, który złamany psychicznie „wsypał wszystkich znanych mu osobiście członków AK w Jędrzejowie") ${ }^{19}$. W przygotowywanej z pośpiechem akcji dużą rolę odegrał „Wiktor”. Siedziba Kripo, w której pracował, mieściła się w tym samym budynku co siedziba Gestapo. E. Adamczyk miał więc ułatwione zadanie obserwowania wszystkiego, co się tam działo. Wszelkie informacje dotyczące aresztowanych ludzi przekazywał natychmiast Komendzie Obwodu Jędrzejów AK, a według jego własnej relacji miał być inicjatorem odbicia aresztowanych ${ }^{20}$. Główne zadanie w tej akcji

17 A. Ropelewski: Wspomnienia z AK. Warszawa 1957, s. 48-49; IDEm: W Jędrzejowskim Obwodzie..., s. 84-89. W zasobach IPN w Kielcach znalazłam informację o jednej ze zbrodni H. Kappa na ludności cywilnej. 22 kwietnia 1970 roku przed sądem we Włoszczowej w obecności prokuratora z Powiatowej Komisji Badania Zbrodni Hitlerowskich w Kielcach jako świadek stanął Jan Napora z Irządz. Opowiedział historię z czasów niemieckiej okupacji o jadących (prawdopodobnie do Szczekocin) na furmance 5 osobach: Stanisławie Niedzielskim z Irządz, Weronice i Janie Falskich z Wygiełzowa i państwu Kawałek z Bodziejowic. „Na drodze w miejscowości Zawada dojechał dowódca żandarmerii z Jędrzejowa zwany »Kap« i on osobiście rozstrzelał wszystkie osoby siedzące na furmance". AIPN, sygn. Ki Ds 11/70, T. 1, Zbrodnie zabójstwa 16 Polaków we wsi Irządze w 1939 r., k. 8. Pochodzący z Kuźni Raciborskiej Helmut Kapp naprawdę nazywał się Konstanty Kapuścik. W końcu 1941 roku stwierdził, że „nie może się posługiwać tym "pierońskim« polskim nazwiskiem”. E. ADAмсzy к ps. „Wiktor”: Mój udział w kontrwywiadzie..., s. 77, 147.

18 A. Soкó£: Związek Walki Zbrojnej - Armia Krajowa w Jędrzejowskiem w latach 1940-1945. „Studia Historyczne” 1983, t. 26, 4 (103), s. 674; IDEм: Ruch oporu..., s. 266-267.

19 A. Ropelewski: W Jędrzejowskim Obwodzie..., s. 156. Ponieważ E. Adamczyk był w siedzibie Gestapo, kiedy przesłuchiwano H. Blicharskiego, dowiedział się o wydaniu nazwisk członków AK i ich ostrzegł, lecz ci ostrzeżenie zlekceważyli. E. ADA мCZy к ps. „Wiktor”: Mój udział w kontrwywiadzie..., s. 188-189.

20 A. Ropelewski: W Jędrzejowskim Obwodzie..., s. 157; E. AdAмCZy к ps. „Wiktor”: Mój udziat w kontrwywiadzie..., s. 192. 
S. Gądzio „Kos” powierzył grupie dywersyjnej AK z rejonu Wodzisławia, którą dowodził Józef Maj „Ballet”, zamieszkały we wsi Olszówka Nowa koło Wodzisławia $^{21}$. Akcja uwolnienia więźniów zakończyła się powodzeniem ${ }^{22}$, a wydarzenie to nazwano ,jędrzejowską akcją pod arsenałem”. W budynku było ok. 14 członków Gestapo. Gdy doszło do strzelaniny, „zgasili światła i zabarykadowali się w swoich pomieszczeniach”23. Byli zaskoczeni i nieprzygotowani. Jeden z nich „Na wezwanie Balleta — »Ręce do góry « [...] krzyknął tylko "Rany boskie, bandyci! «"24. Inni nie mieli nabitych pistoletów ${ }^{25}$. Potrafili jednak wziąć odwet na bezbronnych. Dzień po akcji, 3 lutego, zastrzelono H. Blicharskiego, a 19 lutego koło Słowika pod Kielcami -7 mieszkańców Jędrzejowa ${ }^{26}$.

Dramatem, któremu kontrwywiad Obwodu Jędrzejów nie zdołał zapobiec, była pacyfikacja wsi Swaryszów, podczas której zginął m.in. Józef Adamczyk „Zwijak”, brat „Wiktora” 27 . Jak do tego doszło? Otóż w połowie kwietnia 1944 roku krakowskie Gestapo umieściło w Szpitalu św. Łazarza więźnia Henryka Janiaka. Ten zaczął opowiadać, że należy do AK i przedstawiał się jako bardzo zasłużony członek tej organizacji. W jego opowieści nikt nie wątpił, darzono go powszechnym szacunkiem. W szpitalu H. Janiak poznał — pochodzącą ze wsi Podsadek — Janinę Błaut. Ta zwierzyła się, że w pobliskim jej rodzinnej miejscowości Swaryszowie działa wielu członków AK, a ona może pomóc mu za ich pośrednictwem uciec ze szpitala. 1 sierpnia zniecierpliwiony H. Janiak sam opuścił szpital, zabierając ze sobą J. Błaut, wówczas już swoją narzeczoną. Oboje udali się do wsi Swaryszów, gdzie J. Błaut poprosiła należącego do AK Józefa Noculaka o schronienie dla H. Janiaka. Ten zdołał zdobyć zaufanie miejscowych, przebywając 10 dni we wsi, poznał wszystkich żołnierzy AK. Obiecał im, że zdobędzie i przywiezie do Swaryszowa dużą ilość broni, zaznaczając jednak, że uzbrojenie zostanie dostarczone samochodem ciężarowym, a ludzie, którzy je przywiozą będą ubrani w niemieckie mundury. Nie powinni się jednak przestraszyć. 10 sierpnia odjechał ze stacji Sędziszów do Częstochowy, rzekomo po obiecaną broń. Na odjezdnym H. Janiak obiecał, że wkrótce wróci do Swaryszowa. I rzeczywiście wrócił...

16 sierpnia do siedziby Gestapo w Jędrzejowie przyjechali członkowie Gestapo z Częstochowy. Jeden z nich, określany jako „Heniek”, zwrócił uwagę będącego w tym dniu na służbie E. Adamczyka, ponieważ doskonale władał językiem polskim. W rozmowie z „Wiktorem” powiedział, że jest Polakiem, siłą zmuszonym do

\footnotetext{
${ }^{21}$ A. Ropelewski: W Jędrzejowskim Obwodzie..., s. 157.

22 Ibidem, s. 157-160; A. Soкó£: Ruch oporu..., s. 267.

${ }^{23}$ A. Ropelewski: W Jędrzejowskim Obwodzie..., s. 161.

${ }^{24}$ E. АдАмсZук ps. „Wiktor”: Mój udział w kontrwywiadzie..., s. 199.

${ }^{25}$ Ibidem, s. 201.

26 A. Ropelewski: W Jędrzejowskim Obwodzie..., s. 161.

${ }_{27}$ AIPN, sygn. Ka 02/132, T. 1, Kwestionariusz ewidencyjny..., k. 47v; A. Soкó£: Związek Walki Zbrojnej..., s. 675 .
} 
wstąpienia w szeregi Wehrmachtu, a potem przeniesiony do Gestapo. Wspomniał także, że jest przygotowywana wielka obława na polskich „bandytów”. Nie podał jednak nazwy miejscowości ani żadnych szczegółów. E. Adamczyk nie wiedział nic o pobycie kilka dni wcześniej „wielkiego bohatera” AK w Swaryszowie. Podejrzewał, że jeśli jędrzejowskie i częstochowskie oddziały Gestapo planują jakąś wspólną akcję, to spodziewana obława powinna się odbyć w powiecie włoszczowskim, dlatego też poinformowano niezwłocznie o niebezpieczeństwie zwierzchnictwo tamtejszego AK. Uderzenie nastąpiło jednak gdzie indziej. Wczesnym rankiem 17 sierpnia 1944 roku pod miejscowość Swaryszów podjechało ok. 40 ciężarowych samochodów, z których wysiadło blisko 500 ludzi. Z domów zaczęto wyciągać mieszkańców i spędzać ich na jeden plac. Około godziny 15 rozpoczęto segregację ludności, polegającą na tym, że jeden z gestapowców wskazywał, do której z dwóch grup ma trafić każdy z mężczyzn. Na końcu okazało się, że jedna z dwóch formowanych grup liczy 40 osób, wszyscy to członkowie AK. Spośród 40 mężczyzn 5 odwieziono na przesłuchanie do Jędrzejowa, natomiast pozostałych 35 zapędzono na skraj wioski i tam mordowano ${ }^{28}$. „Rozjuszeni hitlerowcy, uzbrojeni w drągi, widły, cepy, żelazne pręty i inne niebezpieczne narzędzia, rzucili się z niebywałą furią na bezbronnych skazańców i poczęli ich bić w niesamowity sposób. Rozbijano nieszczęśnikom głowy, wybijano im oczy, przetrącano kończyny, kopano i kłuto tych, co pod razami upadli na ziemię"29. Po latach „Wiktor” napisze: „W moim osobistym odczuciu uważałem, że jako kierownik kontrwywiadu poniosłem bolesną porażkę"30.

Ponieważ wśród ofiar pacyfikacji był brat E. Adamczyka, bojąc się o swoje bezpieczeństwo, „Wiktor” zrezygnował z pracy w Kripo i zaczął się ukrywać31. Z rozmów z mieszkańcami Swaryszowa i swoimi kolegami z posterunku w Jędrzejowie wywnioskował, że H. Janiak, obiecujący transport broni swaryszowskim członkom AK i gestapowiec „Heniek”, z którym rozmawiał w siedzibie Gestapo, to ta sama osoba. Za sprawą „Wiktora” na H. Janiaka wydano wyrok śmierci, którego niepodległościowe podziemie nie zdołało jednak wykonać ${ }^{32} .13$ marca 1949 roku został aresztowany ${ }^{33}$ na podstawie doniesienia E. Adamczyka do prokuratora

28 E. AdAмсzy к ps. „Wiktor”: Mój udział w kontrwywiadzie..., s. 235-266.

29 Ibidem, s. 255. Zob. także: H. Strzelecki: Swaryszów, pow. Jędrzejów. W: Chleb i krew. Moja wieś w czasie okupacji. Wspomnienia. Oprac. T. Kisıelewski, J. NowAK. Warszawa 1968, s. 482488 - z relacji tej wynika, że mieszkańcy Swaryszowa dopiero po pewnym czasie powiązali pobyt „Henryka” w ich wsi z pacyfikacją.

30 E. AdAмсzy к ps. „Wiktor”: Mój udział w kontrwywiadzie..., s. 258.

31 Ibidem, s. 259.

32 Ibidem, s. 262-264.

33 AIPN, sygn. Ki 013/3127, Akta śledztwa w sprawie współpracy z Niemcami w okresie okupacji przez doprowadzenie do aresztowania i rozstrzelania członków organizacji AK, prowadzonego przeciwko: Henryk Janiak, imię ojca: NN, ur. 01-05-1915 rok, tj. podejrzanemu o popełnienie przestępstwa z art. 1 Dekretu PKWN z dn. 31-08-1944 r. o wymiarze kary dla faszystowsko- 
Staszkiewicza. „Wiktor” złożył zeznania o swaryszowskiej tragedii, kiedy był już osadzony w więzieniu w Kielcach. W akcie oskarżenia przeciwko H. Janiakowi można było przeczytać: „idąc na rękę okupacyjnej władzy państwa niemieckiego, w dniu 17 sierpnia 1944 r. w miejscowości Swaryszów, gm. Mstyczów, pow. Jędrzejów przebrany w mundur gestapo brał udział w przeprowadzonej przez gestapo pacyfikacji w/w miejscowości, wskazując członków konspiracyjnych organizacji, w wyniku czego zostało rozstrzelanych 35 obywateli polskich" ${ }^{34}$. Rola H. Janiaka podczas pacyfikacji była znacząca, gdyż to on decydował, kto będzie żyć, a kto umrze. „Siedzący w samochodzie Janiak Henryk segregował przechodzących ludzi na lewo lub prawo, używając do tego wyrazów niemieckich »links - rechts «"35. Proces przeciwko niemu ruszył 17 października 1949 roku. Na liście 19 osób do wezwania na rozprawę w charakterze świadków na pierwszym miejscu widnieje nazwisko E. Adamczyka, który przebywał wówczas ciągle w więzieniu ${ }^{36}$. W uzasadnieniu aktu oskarżenia znajduje się informacja, że H. Janiak po zakończeniu pacyfikacji w nagrodę za wyświadczone usługi dostał od Niemców ubranie i buty oraz został zwolniony z aresztu ${ }^{37} .13$ marca 1950 roku przed Sądem Apelacyjnym w Kielcach odbyła się główna rozprawa. W protokole zapisano, że H. Janiak przyznał się do zarzucanej winy, podkreślając, że działał jako więziony przez Niemców ${ }^{38}$. Jako pierwszy świadek oskarżenia był przesłuchiwany E. Adamczyk, który stwierdził, że na dzień przed pacyfikacją widział w siedzibie Gestapo w Jędrzejowie H. Janiaka w mundurze Gestapo. Uczestniczył wówczas w naradzie na temat przygotowywa-

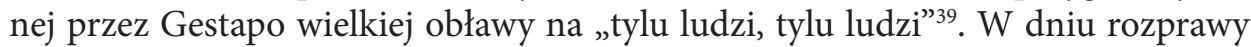
głównej sąd uznał H. Janiaka za winnego zarzucanej zbrodni i skazał go na karę śmierci ${ }^{40}$. W uzasadnieniu wyroku sąd podkreślił rolę zeznań E. Adamczyka, który był świadkiem wydarzeń rozgrywających się w Jędrzejowie na dzień przed obławą, i zgodność jego zeznań z zeznaniami wielu innych świadków, którzy znali

-hitlerowskich zbrodniarzy winnych zabójstw i znęcania się nad ludnością cywilną i jeńcami oraz dla zdrajców Narodu Polskiego, k. 4.

${ }^{34}$ Ibidem.

${ }^{35}$ AIPN, sygn. Ki 126/74, Akta sprawy karnej przeciwko: Janiak Henryk oskarżonemu z art. 1 pkt 2 Dekretu PKWN z dn. 31-08-1944 r. o wymiarze kary dla faszystowsko-hitlerowskich zbrodniarzy winnych zabójstw i znęcania się nad ludnością cywilną i jeńcami oraz dla zdrajców Narodu Polskiego, tj. o wydanie w ręce Gestapo czterdziestu członków AK w następstwie czego zostali rozstrzelani, k. 8.

${ }^{36}$ Ibidem, k. 7, 9.

${ }^{37}$ AIPN, sygn. Ki 013/3127, Akta śledztwa..., k. 5; AIPN, sygn. Ki 126/74, Akta sprawy karnej..., k. 9.

${ }^{38}$ AIPN, sygn. Ki 126/74, Akta sprawy karnej..., k. 243-245.

${ }^{39}$ Ibidem, k. 246-248.

40 AIPN, sygn. Ki 013/3127, Akta śledztwa..., k. 9; AIPN, sygn. Ki 126/74, Akta sprawy karnej..., k. $263-264$. 
wydarzenia swaryszowskie z autopsji ${ }^{41}$. Z 17 marca 1950 roku pochodzi zapowiedź rewizji od wyroku, napisana przez Jerzego Sulimierskiego, adwokata H. Janiaka ${ }^{42}$, którą odrzucono z przyczyn formalnych 15 kwietnia $1950 \mathrm{roku}^{43}$. Dnia 23 kwietnia 1950 roku skazany na śmierć poprosił o ułaskawienie prezydenta ${ }^{44}$. Z listu z 27 listopada 1950 roku nadanego z Generalnej Prokuratury RP — Biura Ułaskawień wynika, że prezydent Bierut odmówił prawa łaski wobec skazanego na karę śmierci (bez podania przyczyny) ${ }^{45}$. H. Janiak został stracony 1 grudnia $1950 \mathrm{roku}^{46}$.

Cieniem na życiorysie E. Adamczyka kładą się jedynie relacje na jego temat, jakie wyszły spod pióra Mariana Sołtysiaka „Barabasza”, który dowodził partyzanckimi działaniami AK w Górach Świętokrzyskich. Pisał on o „Wiktorze”: „Sieć konfidentów w terenie tworzył w zasadzie Adamczyk. W działalności swej stosował chytre i pozornie przekonywające metody. Dowodził kaptowanemu, że sam zainteresowany jest wyłącznie walką z bandytyzmem, że sympatyzuje nawet $\mathrm{z}$ ruchem niepodległościowym. Postawa taka często zjednywała przychylność, niewielu ponadto zdawało sobie sprawę z istoty pracy kripo"47. 17 lipca 1943 roku M. Sołtysiak „Barabasz” miał wyznaczyć 7 podległych sobie ludzi celem „uchwycenia i uprowadzenia" E. Adamczyka. Zamach się jednak nie powiódł, w drodze do Kielc wyznaczeni ludzie zostali ostrzelani przez Niemców, tylko 2 z 7 przeżyło ${ }^{48}$.

Nie wiadomo, skąd biorą się oskarżenia wobec E. Adamczyka. Wiadomo natomiast, że podlegli „Barabaszowi” żołnierze, podobnie jak on sam, byli oskarżani o zbrodnie na ludności cywilnej, przede wszystkim na Żydach ${ }^{49}$. M. Sołtysiak z czasem pogodził się z nową rzeczywistością, jaka nastała po zakończeniu II wojny światowej. Z 1965 roku pochodzi list „Barabasza” do jego byłego podkomendnego Henryka Pawelca „Andrzeja”, w którym w sposób agitacyjny przedstawił bardzo pozytywny obraz PRL ${ }^{50}$. Wiadomo, że już w wolnej Polsce środowisko partyzantów „Barabasza” było skłócone, a ich aktywnością w czasie wojny interesowała się prokuratura. Być może M. Sołtysiak nie do końca orientował się w rzeczywistej działalności E. Adamczyka, wszak nie wiedział wszystkiego na temat jego osoby (uznał go np. za urodzonego w Rybniku, a nie w $\operatorname{Irządzach}^{51}$ ). Na tak złą opinię o „Wiktorze” wpływ mogła mieć także cenzura, która nie pozwalała publikować informacji o za-

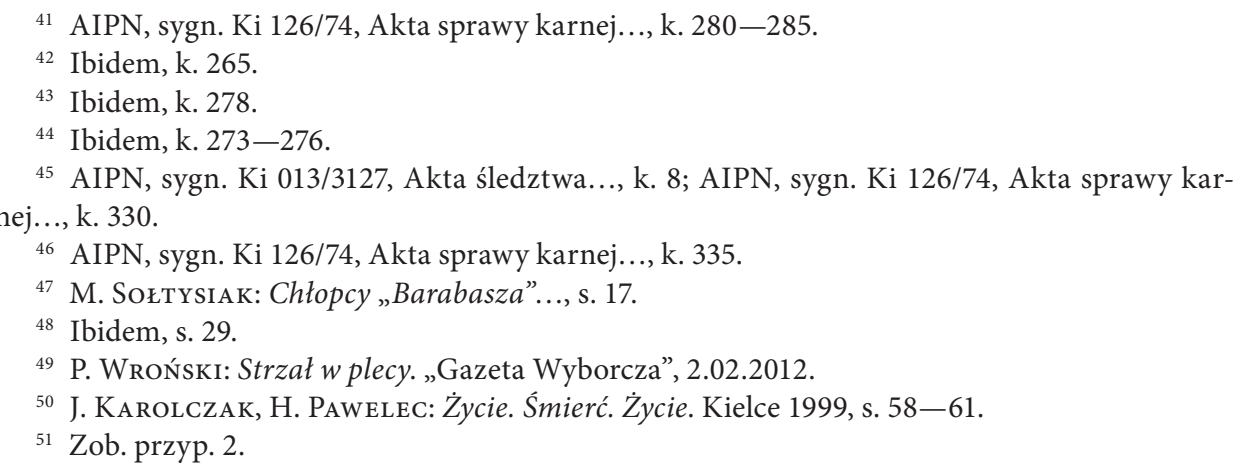


sługach osoby uznanej za persona non grata. Przykładowo, wydana w 1967 roku przez PAX książka Chłopcy „Barabasza” pozbawiona została przez cenzurę wielu fragmentów. W podobnym tonie co M. Sołtysiak „Barabasz” o „Wiktorze” wypowiadał się Zygmunt Firley „Kajtek”, którego „Barabasz” był dowódcą ${ }^{52}$. W zasobach IPN nie znalazłam jednak żadnej, niewytworzonej przez aparat bezpieki, wzmianki o antypolskiej działalności E. Adamczyka. Natomiast jego, wydawałoby się czasem zmyślone, historie o bohaterstwie, które spisał w wydanych Wspomnieniach znajdują potwierdzenie w zachowanym bogatym materiale archiwalnym.

E. Adamczyk był ostatnim szefem wywiadu AK w Okręgu Radomsko-Kieleckim ${ }^{53}$. Koniec wojny zastał go w Jędrzejowie, w stopniu podporucznika. Po wojnie nadal pozostawał w konspiracji AK. 22 marca 1947 roku ujawnił w Powiatowym Urzędzie Bezpieczeństwa Publicznego w Gliwicach swą działalność w ZWZ i AK. Nie oddał jednak broni, którą wcześniej ukrył. 15 października 1948 roku został aresztowany przez Urząd Bezpieczeństwa Publicznego w Kielcach za współpracę z Niemcami ${ }^{54}$. 9 lutego 1949 roku „Wiktor” został uniewinniony, po czym po 14 dniach pobytu na wolności, tj. 24 lutego, ponownie go aresztowano ${ }^{55}$. Już po pierwszym aresztowaniu podejmowano próby jego obrony. Z 2 stycznia 1949 roku pochodzi oświadczenie byłego posła z PSL „Wyzwolenie”, redaktora „Wiadomości Chłopskich” i więźnia Oświęcimia — Jana Ledwocha z Irządz. Wspomniał on, że E. Adamczyk w 1941 roku ostrzegł jego i jego towarzyszy: Jana Kasperczyka i Franciszka Wronę, o rozkazie Gestapo aresztowania ich ${ }^{56}$. Wcześniej, pismem z 18 kwietnia 1947 roku nienaganną opinię wystawili „Wiktorowi” mjr Kasper Niemirski

52 Z. Firley: W Kedywie $i$ w „Burzy”. Warszawa 1988, s. 97-98.

53 W. Вовzовонату „Jodła”: Okręg Radomsko-Kielecki ZWZ-AK 1939-1945. Warszawa 1988, s. 235; S. Piątкowski: Wywiad ZWZ-AK w Okregu Radomsko-Kieleckim (1940-1945) ze szczególnym uwzględnieniem obwodu radomskiego. W: Armia Krajowa. Okręg Radomsko-Kielecki. Red. A. Massalski, S. Meducki. Kielce 1999, s. 76.

54 AIPN, sygn. Ka 02/132, T. 1, Kwestionariusz ewidencyjny..., k. 47v; AIPN, sygn. Ka 032/29, Ankiety osobowe..., k. 32; AIPN, sygn. Ki 126/60, Akta sprawy karnej..., k. 63.

${ }^{55}$ Ibidem, k. 261; AIPN, sygn. Ki 013/1360, Akta śledztwa w sprawie współpracy z Niemcami w okresie okupacji przez doprowadzenie do aresztowania i rozstrzelania członków organizacji AK, udziału w zabójstwie czterech obywateli polskich narodowości żydowskiej, prowadzonego przeciwko: Henryk Janiak, ur. 01-05-1915 rok i innym, tj. podejrzanym o popełnienie przestępstwa z art. 1 pkt 1, art. 1 pkt 2 Dekretu PKWN z dn. 31-08-1944 r. o wymiarze kary dla faszystowsko-hitlerowskich zbrodniarzy winnych zabójstw i znęcania się nad ludnością cywilną i jeńcami oraz dla zdrajców Narodu Polskiego; art. 23 KK w zw. z art. 1 pkt 1 Dekretu PKWN z dn. 31-08-1944 r. o wymiarze kary dla faszystowsko-hitlerowskich zbrodniarzy winnych zabójstw i znęcania się nad ludnością cywilną i jeńcami oraz dla zdrajców Narodu Polskiego, k. 64 - 66, 75; AIPN, sygn. Ki 126/61, Akta sprawy karnej przeciwko: Adamczyk Eugeniusz oskarżonemu z art. 1 pkt 2 i art. $4 \$ 1$ Dekretu PKWN z dn. 31-08-1944 r. o wymiarze kary dla faszystowsko-hitlerowskich zbrodniarzy winnych zabójstw i znęcania się nad ludnością cywilną i jeńcami oraz dla zdrajców Narodu Polskiego, tj. o współpracę z niemiecką Sicherheitsdienst, k. 236-237.

56 AIPN, sygn. Ki 126/60, Akta sprawy karnej..., k. 281. 
„Mir”, komendant Obwodu Jędrzejów AK, i kapitan Jan Puto „Wrzos”: „Stwierdzamy, że Ob. Adamczyk Eugeniusz »Wiktor « [...] należał do AK od 1940 r. Pełnił funkcję kierownika wywiadu i kontrwywiadu. Ochronił szereg osób od aresztowania przez tępienie agentów gestapo. Oddał organizacji wiele cennych usług. Za wybitne zasługi awansował do stopnia por. rezerwy i został odznaczony Srebrnym Krzyżem Zasługi" 57 .

Po ponownym aresztowaniu „Wiktora” wszczęto po raz kolejny „śledztwo”. W tych okolicznościach nie jest chyba przypadkiem, że 5 maja 1949 roku do Wojewódzkiego Urzędu Bezpieczeństwa Publicznego wpłynął donos, podpisany przez „Kratę", informujący m.in., że E. Adamczyk, jako pracownik Kripo w Jędrzejowie, stosował podczas przesłuchań tortury, „dawał wyroki do Oświęcimia” czy też okradał więźniów ${ }^{58}$. Z „ustaleń” Zdzisława Baszewskiego, oficera śledczego Wojewódzkiego Urzędu Bezpieczeństwa Publicznego w Kielcach, które poznajemy z pisma z 9 czerwca 1949 roku, wynika, że „w okresie okupacji od 1940 r. do 1944 r. ADAMCZYK Eugeniusz pełniąc obowiązki funkcjonariusza Kryminalnej P.P. w Jędrzejowie, był płatnym agentem "gestapo « pod ps. »Karliczek« i zarazem jako członek »dwójki« $[\mathrm{AK}]$ pod ps. »Poleski«, a później »Wiktor «, następnie IMBOR Zdzisław ps. »Duch «, jako kierownik II-go Referatu w Obwodzie »AK« — Jędrzejów, w czasie od 1940 r. do 1943 r., oraz WIŚNIEWSKI Stanisław ps. "Gruby«, również jako kierownik tegoż Referatu, w czasie od 9 czerwca 1943 r. do jesieni 1944 r. idąc na rękę władzy państwa niemieckiego, działali na szkodę obywateli polskich, przez to, że IMBOR i WIŚNIEWSKI po rozpracowaniu członków ruchu lewicowego celowo przekazywali ich nazwiska ADAMCZYKOWI jako agentowi "gestapo«, w następstwie czego szereg osób zostało aresztowane i skierowane do obozu w Oświęcimiu" ${ }^{9}$. Jak można wnioskować z pewnego dokumentu wystawionego przez Izbę Karną Sądu Najwyższego, to prokuratura w Kielcach zażądała uchylenia wyroku uniewinniającego i ponownego rozpatrzenia sprawy ${ }^{60}$. O przygotowaniu do kolejnego procesu, odbity niegdyś z katowni Gestapo przez „Wiktora” Zbigniew Białkiewicz „Świerk” napisał: „Usiłowano go zmusić do przyznania się do winy, żeby zrobić pokazowy proces. Stosowano metody, których nie powstydziliby się oprawcy z gestapo. Potrafili go np. trzymać przez miesiąc w karcerze boso na betonie, w tak ciasnej celi, że mógł tylko stać, nie wolno mu było zasnąć, przez 6 dni nie otrzymywał nic do jedzenia, a następnie dostawał co czwarty posiłek"61.

20 lutego 1950 roku przed sądem rozpoczął się proces przeciwko E. Adamczykowi. Przewodniczył sędzia Stanisław Jabłoński. Na ławie oskarżonych zasiedli

\footnotetext{
${ }^{57}$ Ibidem, k. 352.

58 AIPN, sygn. Ki 013/1360, Akta śledztwa..., k. 183.

${ }^{59}$ AIPN, sygn. Ki 126/60, Akta sprawy karnej..., k. 253.

${ }^{60}$ Ibidem, k. 255.

${ }^{61}$ Z. BiAŁKiewiCZ: Mowa pożegnalna..., s. 281-282.
} 
także Zdzisław Imbor „Duch” oraz Stanisław Wiśniewski ${ }^{62}$. W sentencji wyroku czytamy:

I. w latach 1941 - 1943 w Jędrzejowie, idąc na rękę władzy państwa niemieckiego, działali na szkodę Jana Ledwocha, Urbańskiego, Władysława Lubonia, Pękalskiego, Dra Kwarty, Patrzałka, Jureczko, Madejskiego, Nowaka, Łatosia i in. przez wskazanie ich tajnej niemieckiej policji Gestapo jako członków podziemnej organizacji lewicowej. Tychże Zdzisława Duch - Imbora i Eugeniusza Adamczyka o to, że II. w 1942 roku daty bliższej nieustalonej idąc na rękę władzy państwa niemieckiego na terenie powiatu jędrzejowskiego, pierwszy wydał polecenie zastrzelenia członka organizacji lewicowej pseudo „Sosnę”, drugi zaś w zamiarze wykonania tego polecenia poszukiwał „Sosny”, lecz zamierzonego czynu nie dokonał, gdyż „Sosna” zdołał się ukryć. Tegoż Zdzisława Duch — Imbora o to, że III. w listopadzie 1942 roku w Olszówce Nowej, idąc na rękę władzy ${ }^{63}$ państwa niemieckiego, wziął udział w zabójstwie czterech obywateli polskich narodowości żydowskiej i przez wydanie polecenia Oddziałowi dywersyjnemu A.K. do ich zastrzelenia, które to polecenie zostało wykonane. Tegoż Eugeniusza Adamczyka o to, że IV. zimą 1941 roku we wsi Chyrzy, gm. Węgleszyn, pow. Jędrzejowskiego, idąc na rękę władzy państwa niemieckiego, wziął udział w aresztowaniu Józefa Jaskólskiego, Kazimierza Rutkowskiego, Tadeusza Sobali, Wincentego Limanowskiego i in. podejrzanych o komunizm. V. 20 stycznia 1943 roku w Przełaju, gm. Mstyczów, idąc na rękę władzy państwa niemieckiego, wziął udział w aresztowaniu członków P.P.R. Stanisława Zasady, Jana Zasady, Stanisława Gąsiorowskiego, Mieczysława Celbana, Jana Pabjańczyka i in., którzy zostali wywiezieni do obozu koncentracyjnego. VI. w czasie od kwietnia $1941 \mathrm{r}$. do końca 1944 r. w Kielcach i w Jędrzejowie, brał udział w organizacji przestępczej powołanej przez władze państwa niemieckiego, przyjmując stanowisko konfidenta w niemieckiej służbie bezpieczeństwa „Sicherheits Diennst" [właściwa nazwa to Sicherheitsdienst des Reichsführers SS - K.M.] i pracując w tymże charakterze. VII. Dnia 7 czerwca 1944 r. w Radomiu, idąc na rękę władzy państwa niemieckiego, działał na szkodę polskich organizacji komunistycznych, przez złożenie do „Sicherheitspo-

${ }^{62}$ AIPN, sygn. Ki 126/88, Akta sprawy karnej przeciwko: Adamczyk Eugeniusz, Imbor — Duch Zdzisław, Wiśniewski Stanisław oskarżonym z art. 1 pkt 2 Dekretu PKWN z dn. 31-08-1944 r. o wymiarze kary dla faszystowsko-hitlerowskich zbrodniarzy winnych zabójstw i znęcania się nad ludnością cywilną i jeńcami oraz dla zdrajców Narodu Polskiego, tj. o wskazanie Gestapo członków podziemnej organizacji lewicowej, k. 511.

${ }^{63}$ Ibidem, k. 646. 
lizei" telegraficznego meldunku o istnieniu na terenie Miechowa komunistycznych szkół ${ }^{64}$.

Za rzekomy udział we wspomnianych przestępstwach „Wiktor” został skazany na karę łączną 10 lat więzienia, utratę praw publicznych i obywatelskich praw honorowych na lat 5 oraz przepadek całego mienia. Zdzisław Imbor „Duch” i Stanisław Wiśniewski zostali uniewinnieni ${ }^{65}$. Na mocy decyzji Sądu Najwyższego kara dla E. Adamczyka została zmniejszona o połowę. 23 stycznia 1952 roku został zwolniony warunkowo od dalszego odbywania kary. Obawiając się ponownego aresztowania, ukrywał się aż do 1956 roku. Jak czytamy w ankiecie: „Po wyjściu z więzienia rozpoczął wrogą działalność, wysyłając listy anonimowe do różnych instytucji państwowych, aktywistów partyjnych i działaczy społecznych, szkalując ustrój PRL, grożąc karą śmierci pod nazwą "Samoobrona Narodu«, nawołując do zaniechania aktywnej pracy"66.

Jak wynika z materiałów IPN dotyczących osób ujawnionych w czasie amnestii w 1956 roku (26 kwietnia), E. Adamczyk ponownie przyznał się w Wojewódzkiej Prokuraturze w Katowicach do działalności w organizacjach niepodległościowych ${ }^{67}$. Od czerwca 1956 roku pracował w Energoprojekcie w Gliwicach, rok później zaczą pracę na Wydziale Elektrycznym Politechniki Śląskiej. Jak miało wynikać z zeznań II sekretarza KZ PZPR i dziekana Wydziału Elektrycznego, E. Adamczyk „przy pomocy żony pisał anonimy na pracowników dziekanatu oraz do ich rodzin" ${ }^{\prime 68}$. Wprawdzie nie zostało to udowodnione, niemniej przeniesiono go do pracy na Wydział Górniczy. Czytając akta „Wiktora”, można odnieść wrażenie, że stawiał bierny opór „słusznej” linii władzy: „Politycznie nie angażuje się, do ustroju PRL ustosunkowany $\mathrm{z}$ rezerwą, pod względem moralnym prowadzi się należycie. Udziału w życiu społecznym nie bierze, zdecydowanie odmawia podejmowania się pracy o charakterze społecznym, co stwarza opinie, że unika związania się z pozytywnym nurtem" 69 .

${ }^{64}$ Ibidem, k. 647.

${ }^{65}$ AIPN, sygn. Ki 013/1360, Akta śledztwa..., k. 215v.

${ }^{66}$ AIPN, sygn. Ka 02/132, T. 1, Kwestionariusz ewidencyjny..., k. 47v; AIPN, sygn. Ka 032/29, Ankiety osobowe..., k. 32; AIPN, sygn. Ki 126/60, Akta sprawy karnej..., k. 63. O akcji poszukiwawczej E. Adamczyka zob. AIPN, sygn. Ka 02/132, T. 3, Sprawa agenturalno-poszukiwawcza kryptonim „Detektyw” dot. Adamczyk Eugeniusz. Z notatki UBP w Gliwicach z 27 sierpnia 1953 roku wiadomo, że o możliwych miejscach pobytu poszukiwanego władzom donosił informator „Błyskawica”, „gdyż jak wynika wg. posiadanych materiałów, to żona poszukiwanego utrzymuje z w/w inf. kontakty koleżeńskie". Ibidem, k. 4.

${ }^{67}$ AIPN, sygn. Ka 063/6, Skorowidz ujawnionych podczas amnestii 1956 r., k. 1; AIPN, sygn. Ka 032/29, Ankiety osobowe..., k. 33.

${ }_{68}$ AIPN, sygn. Ka 032/29, Ankiety osobowe..., k. 33. Zob. także: AIPN, sygn. Ka 02/132, T. 1, Kwestionariusz ewidencyjny..., k. 5-9.

${ }^{69}$ AIPN, sygn. Ka 032/29, Ankiety osobowe..., k. 33. 
Z pochodzącego z 7 stycznia 1969 roku „Wniosku o założeniu sprawy” wynika, że organy bezpieczeństwa państwowego ponownie zainteresowały się E. Adamczykiem. Jak czytamy w dokumentach, miał być on w posiadaniu archiwalnych materiałów Obwodu Jędrzejów AK, na podstawie których chciał wydać „,wspomnienia AK z okupantem". Z zamiarem wydania książki miał podejmować działania, którymi chciał zwrócić na siebie uwagę ambasady USA w Warszawie ${ }^{70}$. Sprawę prowadziła Komenda Miejska Milicji Obywatelskiej w Gliwicach. Można wnioskować, że ponowne kłopoty E. Adamczyka były pokłosiem jego znajomości z tajnym współpracownikiem ps. „Az”. Z 6 listopada 1968 roku pochodzi wyciąg z doniesienia „Aza”. Dowiadujemy się z niego, że wspólnie z E. Adamczykiem uczestniczył on w zebraniach PAX-u. Podczas spotkania „przy kawie” E. Adamczyk miał zwierzyć się „Azowi”, że pisze historyczną pracę o działalności AK na terenie powiatu jędrzejowskiego podczas II wojny światowej. Były członek AK miał ufać „Azowi”, ponieważ żona tego drugiego była Amerykanką. Dodatkowym jego atutem, w ocenie „Wiktora”, był fakt, że miał on lecieć do USA z przesiadką w Londynie. Nieświadomy niczego E. Adamczyk poprosił tajnego współpracownika o przewiezienie rękopisu jego pracy i dostarczenie go polonijnym działaczom w USA celem wydania książki ${ }^{71}$. Miał także przewieźć list do Związku Kombatantów AK w Wielkiej Brytanii. Z notatki por. Jana Turleja z gliwickiej milicji z 7 listopada 1968 roku wynika, że to „koledzy z Włoszczowy”, którzy odwiedzili E. Adamczyka w tym samym roku, mieli poprosić go o opracowanie wspomnień z działalności $\mathrm{AK}^{72}$. Z 13 listopada 1968 roku zachował się kolejny donos „Aza”, według którego E. Adamczyk miał go prosić, aby będąc w ambasadzie amerykańskiej w Warszawie, skontaktował go z pracownikiem ambasady. Tą drogą przygotowujący się do pisania pracy „Wiktor" chciał zgromadzić materiały historyczne wydane na Zachodzie. Adamczyk miał nieopatrznie zwierzyć się „Azowi”, że niedawno był w Jędrzejowie, by odkopać ukryte w czasie okupacji archiwalne materiały AK. „Mówił, że w kilku słojach po cukierkach miał tam różne broszury i wydawnictwa okupacyjne, jak również jakieś listy i spisy towarzyszy z lat okupacji. Część z tego uległa zniszczeniu, ale dużą część uratował i teraz szerzy te materiały i podkleja. Kilka ulotek, które pochodziły z wykopanych przez niego materiałów, ADAMCZYK pokazał mi. Były to małe ulotki z rysunkami, które humorystycznie traktowały okupantów. Pod rysunkami były wierszyki, które piętnowały np. chłopów, którzy gorliwie dostarczają

${ }^{70}$ AIPN, sygn. Ka 02/132, T. 1, Kwestionariusz ewidencyjny..., k. 3-3v.

${ }^{71}$ AIPN, sygn. Ka 02/132, T. 1, Kwestionariusz ewidencyjny..., k. 10-10v. TW „Az” to zapewne Andrzej Ziółkowski, pracownik umysłowy Zakładów Mechanicznych w Łabędach. Wnioskuję tak z informacji o jego ślubie z „obywatelką USA pochodzenia polskiego” Wandą Suchan. AIPN, sygn. Ka 001/205, Teczka personalna tajnego współpracownika pseudonim „AZ” dot. Ziołkowski/ Ziółkowski Andrzej, k. 26-27.

72 AIPN, sygn. Ka 02/132, T. 1, Kwestionariusz ewidencyjny..., k. 12. 
okupantowi zboże itp."73. W kolejnym doniesieniu, z 19 listopada 1968 roku, „Az” informował o swej rozmowie z E. Adamczykiem, który miał wyznać, że nie chce przejść do pracy wywiadowczej dla Ameryki, „ale chciałbym, aby oni [tj. amerykańscy politycy - K.M.] wiedzieli, że mają tutaj ludzi, na których mogą liczyć w 100\% i żeby wiedzieli, kim ci ludzie są i gdzie ich ewentualnie znaleźć" ${ }^{74}$. Poprzez amerykańską ambasadę „Wiktor” chciał uzyskać pomoc w kontakcie ze środowiskiem byłych członków AK w sprawie „Krzyży AK” dla żołnierzy organizacji pozostałych w Polsce oraz w sprawie dostarczenia egzemplarza podręcznika najnowszej historii Polski autorstwa Władysława Pobóg-Malinowskiego ${ }^{75}$. O książkę tę, która zapewne także była potrzebna do pisanej pracy o AK, E. Adamczyk prosił wcześniej profesora Węgrzyna, który wykładając pod Paryżem, miał okazję czasem bywać za granicą, ten jednak bał się ją przewieźć. W zamian zaprowadził E. Adamczyka do domu i pokazał mu inną książkę z Paryża, która (być może ze względu na swą apolityczność) przeszła kontrolę celną, a była to książka... pornograficzna ${ }^{76}$. Z dnia 27 sierpnia 1975 roku pochodzi notatka służbowa z rozmowy sierżanta Ryszarda Grzymały-Turzańskiego z Gliwic i E. Adamczyka odbytej dzień wcześniej. Oto niektóre jej fragmenty:

- Pytanie dotyczące opracowania wspomnień z działalności AK oraz chęć wydania na Zachodzie. Rozmówca oświadczył, że jest w trakcie opracowania wspomnień ${ }^{77} \mathrm{z}$ walk AK ze swojego odcinka pracy, zapewnił, że kopia dawnej pracy zostanie mi natychmiast doręczona, lecz o wydaniu tych wspomnień na Zachodzie nie myślał. Nadmienił, że w chwili obecnej nad opracowaniem wspomnień z walk ZWZ i AK w okręgu jędrzejowskim pracuje dr nauk przyrodniczych Piasecki Hieronim zam. Wrocław pl. Sienkiewicza 100 . W/w był szefem propagandy (Wydz. VI), wydawał gazetkę „W marszu”, działał cały czas w Jędrzejowie. Materiały będą wydane pt. „Kronika ruchu oporu”. Rozmówca wysłał wykaz aresztowanych osób na terenie okręgu jędrzejowskiego. Ostatnio otrzymał od ob. Karczowskiej nauczycielki liceum w Jędrzejowie, list z prośbą o przesłanie nazwisk kobiet, które pracowały w ruchu oporu, która to lista jest potrzebna do opracowania wspomnień o udziale kobiet w walkach z okupantem z okazji Roku Kobiet. Adamczyk przygotował listę kobiet, które pracowały w sekcji

\footnotetext{
${ }^{73}$ Ibidem, k. 13.

${ }^{74}$ Ibidem, k. 14.

${ }^{75}$ Ibidem.

${ }^{76}$ Ibidem, k. 16-17. Zapewne „Wiktor” miał na myśli prof. Stefana Węgrzyna z Politechniki Śląskiej, który także był inwigilowany (i namawiany do współpracy z SB). Zob. Stefan Wegrzyn. In Memoriam. Red. A. Kwiecień, P. Gaj. Gliwice 2012, passim; H. WęGrzyn: Historia życia 19252011. Gliwice 2014, passim.

77 AIPN, sygn. Ka 02/132, T. 1, Kwestionariusz ewidencyjny..., k. 47v.
} 
łączności kierowanej przez ob. Kaleta Teofila ps. „Gotów” zam. Gliwice ul. Wróblewskiego 8 - listę tą pokazywał mi.

- Pod koniec rozmowy nadmienił, że w chwili obecnej udziela się tylko w ZBoWiDzie, gdzie często wygłasza prelekcje. Ostrzegłem rozmówcę, że gdyby kiedykolwiek opracował wspomnienia z walk AK, to muszą one wyjść oficjalnie, każda próba wydania poza granicami kraju będzie traktowana ostro, do odpowiedzialności sądowej włącznie. Rozmówca zapewnił mnie, że do takiej ewentualności nie dojdzie, każde opracowanie przekaże osobiście dla Służby Bezpieczeństwa. Na tą okoliczność pobrałem od rozmówcy oświadczenie, na czym rozmowę zakończono ${ }^{78}$.

W styczniu 1969 roku prokurator powiatowy w Gliwicach nakazał zastępcy komendanta ds. bezpieczeństwa Komendy Miejskiej Milicji Obywatelskiej w Gliwicach zbadać zasadność zarzutów, jakie pod adresem „Wiktora” wysunął Tadeusz Baszak w liście do ówczesnego szefa MON — gen. Wojciecha Jaruzelskiego ${ }^{79}$. W przepełnionej żalem skardze T. Baszak (który przedstawił się jako były żołnierz I Dywizji Piechoty im. Tadeusza Kościuszki i uczestnik szturmu o Berlin) poinformował gen. W. Jaruzelskiego o „Wiktorze”, że to

człowiek, który w przeszłości i teraz czynami swymi godzi w dobro Ludowej Ojczyzny. Napisałem dlatego, że ob. Eugeniusz Adamczyk chwalił się swoją przeszłością, oraz tym, że współpracując z AK jako funkcjonariusz policji niemieckiej, wydawał w ręce gestapo „czerwonych”, oraz wraz ze swoim bratem rozstrzelali dwóch skoczków Radzieckich, którzy chcieli dostać się do partyzantki. A ob. Adamczyk dopuszczał się dalszych wybryków. Między innymi pobił i skopał na Uczelni członka partii ob. Jana Klimkiewicza, wyzywał obraźliwie członka partii inż. Warsza, maltretował obce dzieci i kazał im klęczeć za to, że zbierały kasztany z drzew przed budynkiem Wydz. Elektrycz. Obniżał niesłusznie zarobki sprzątaczkom, powodując u nich uczucie żalu do Państwa Ludowego ${ }^{80}$.

Jak się dowiadujemy z listu T. Baszaka, stanął on przed sądem za oskarżenie E. Adamczyka o przynależność do policji niemieckiej w czasie okupacji ${ }^{81}$. Aby udowodnić słuszność swoich zarzutów, T. Baszak prowadził swoiste prywatne śledztwo, w toku którego ustalił m.in. nazwiska dwóch radzieckich spadochroniarzy

\footnotetext{
78 Ibidem, k. 46. E. Adamczyk używał także pseudonimów (oprócz „Wiktor” i „Poleski”) „Jastrząb” i „Wallenrod”. A. Ropelewski: W Jędrzejowskim Obwodzie..., s. 67 (przyp. 19), 410.

${ }^{79}$ AIPN, sygn. Ka 02/132, T. 1, Kwestionariusz ewidencyjny..., k. 22.

80 Ibidem, k. 23.

${ }^{81}$ Ibidem, k. 23-24.
} 
zastrzelonych rzekomo przez „Wiktora”. Mieli nimi być Konstanty Kapuścik i Julian Tirlinoj ${ }^{82}$. Z 31 grudnia 1968 roku pochodzi wyrok Sądu Powiatowego w Gliwicach, który T. Baszaka uznał za winnego czynu z art. $255 \$ 1$ kk popełnionego wobec E. Adamczyka i skazał na miesiąc aresztu i 500 zł grzywny. T. Baszak musiał zapłacić E. Adamczykowi w sumie 1060 zł kosztów postępowania karnego i zastępstwa adwokackiego ${ }^{83}$. Jak się dowiadujemy z uzasadnienia, z powodu pisma T. Baszaka do władz Politechniki Śląskiej z pomówieniami przeciwko „Wiktorowi” z pracy na uczelni została zwolniona jego żona Adela Adamczyk ${ }^{84}$.

Eugeniusz Adamczyk do końca życia udzielał się społecznie. Działał m.in. w Światowym Związku Żołnierzy AK. Po krótkiej chorobie zmarł 2 stycznia 2000 roku $^{85}$. Pochowany został na Cmentarzu Centralnym w Gliwicach.

\section{Bibliografia}

AdAмсzyк E. ps. „Wiktor”: Mój udział w kontrwywiadzie Armii Krajowej. Warszawa 2007.

Białkiewicz Z.: Mowa pożegnalna wygłoszona przez ppor. AK Zbigniewa Białkiewicza nad trumna zmartego ppor. AK Eugeniusza Adamczyka „Wiktora”. W: E. AdАмсzyк ps. „Wiktor”: Mój udział w kontrwywiadzie Armii Krajowej. Warszawa 2007.

Bовzовонату W. „Jodła”: Okreg Radomsko-Kielecki ZWZ-AK 1939-1945. Warszawa 1988.

Firley Z:: W Kedywie i w „Burzy”. Warszawa 1988.

Karolczak J., Pawelec H.: Życie. Śmierć. Życie. Kielce 1999.

Piątкowski S.: Wywiad ZWZ-AK w Okręgu Radomsko-Kieleckim (1940-1945) ze szczególnym uwzględnieniem obwodu radomskiego. W: Armia Krajowa. Okręg Radomsko-Kielecki. Red. A. Massalski, S. Meducki. Kielce 1999.

Ropelewski A. „Karaś”: Oddział partyzancki „Spaleni”. Toruń 2000.

Ropelewski A.: W Jędrzejowskim Obwodzie AK. Warszawa 1986.

Ropelewski A.: Wspomnienia z AK. Warszawa 1957.

Sокóє A.: Ruch oporu w regionie jędrzejowskim w latach okupacji niemieckiej. „Studia Historyczne” 1987 , t. 30, 2 (117), s. 257-274.

SoKó£ A.: Związek Walki Zbrojnej - Armia Krajowa w Jędrzejowskiem w latach 1940-1945. „Studia Historyczne" 1983, t. 26 (103), s. 663-684.

So£т ysiak M.: Chłopcy „Barabasza”. Warszawa 1971.

Stefan Wegrzyn. In Memoriam. Red. A. Kwiecień, P. Gaj. Gliwice 2012.

Strzelecki H.: Swaryszów, pow. Jędrzejów. W: Chleb i krew. Moja wieśw czasie okupacji. Wspomnienia. Oprac. T. Kisielewski, J. Nowak. Warszawa 1968.

WĘGRZYN H.: Historia życia 1925-2011. Gliwice 2014.

Wroński P.: Strzał w plecy. „Gazeta Wyborcza”, 2.02.2012.

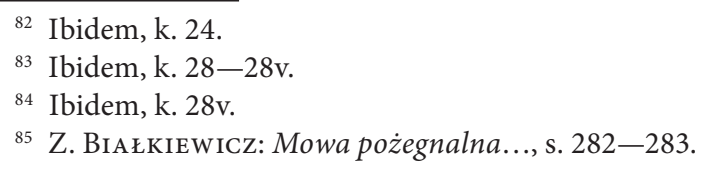




\section{Karolina Maciaszek \\ The head of the Home Army's 2nd Department in Gestapo - Eugeniusz Adamczyk, pseudonym "Wiktor"}

Summary

Eugeniusz Adamczyk, an activist of the Home Army (AK), pseudonym "Wiktor," was undoubtedly a hero of the Polish counterintelligence war meted out against Gestapo. He was in possession of uncommon skills that made him tailored for this kind of work. Born three years prior to the First World War in the village of Irządze, when he sought his first job, he wound up joining the police. At the moment of the outbreak of the Second World War, he had been on duty in the Tarnopol voivodeship. Having reached the General Government, he started to take active part in the operations of the Armed Independence Underground. Instantly after having been sworn in as a member of ZWZ (Union of Armed Struggle), following the order from the union's leadership, he joined the ranks of Gestapo, the Nazi-Germany secret police. While stationed at a Gestapo precinct in Jędrzejów, he was able to aid in various ways those maltreated, tortured and persecuted by Hitlerites, those threatened to be arrested, resettled, or sent to the Reich as "labourers." In the eyes of Poles oblivious to his mission, he was often considered a traitor. In recognition of his services, the Home Army leadership appointed him as a head of its 2nd Department of Intelligence and Counterintelligence in the Jędrzejów Precinct. Yet, a fate filled with hardships awaited him after the war. Twice he was arrested in the 1940s and he had to endure the worst kind of tortures inflicted upon him by the (communist) Security Service. Not until the amnesty of the year 1956 was he allowed to lead relatively normal life. He then became professionally involved at the Silesian University of Technology (Politechnika Śląska). However, he was eventually arrested again for an attempt to publish his memoirs detailing the former work for the Home Army, and for sending death sentences to prominent communist leaders.

Key words: Eugeniusz Adamczyk, the Home Army, counterintelligence, the Second World War 